REFERENCES

Committee of Merchants, Bankers and Traders (1795). An Address to the Public. London: James Phillips. (See Vancouver, John. Cambridge University Library. Bbb. 24. 51.)

Halton, P. and Barton-Wright, E. (1943). J. Soc. chem. Ind. 62, 123.

Hinton, J. J. C. (1944). Biochem. J. 38, 214.

Lepkovsky, S. (1944). Physiol. Rev. 24, 239.

Lister Institute and Medical Research Council. Accessory Food Fuctors Com. mittee (1941). Lancet, 240, 703.

McCance, R. A., Widdowson, E. M., Moran, T., Pringle, W. J. S. and Macrae, T. F. (1945). Biochem. J. 39, 213.

Moran, T. (1945). Nature, Lond., 155, 205.

\title{
Nutritive Value of Proteins Contained in Wheat Flours of Different Degrees of Extraction
}

Dr. H. Chick (Division of Nutrition, Lister Institute, London, S.W.1)

The nitrogenous substances in wheat are almost entirely in the form of protein, the non-protein nitrogenous materials being small in amount and not usually amounting to more than about 5 per cent. of the total. The proteins contained in the different parts of the grain differ in both quantity and quality.

\section{Quantity of Proteins}

Table 1 taken from Osborne and Mendel (1919), and founded on the work of Girard (1884), shows the endosperm to be the fraction poorest in protein. The germ, though containing 30 per cent. of protein, is only about 2 per cent. of the grain, and thus makes a relatively small contribution to the total nitrogen. The bran, comprising 15 per cent. of the

TABLE 1

Protein Content of Fractions of the Wheat Grain

(Protein content $(\mathrm{N} \times 5.7)$ of whole grain 12.5 per cent.)

(From Girard, 1884, and Osborne and Mendel, 1919)

\begin{tabular}{|c|c|c|c|}
\hline \multirow[b]{2}{*}{ Fraction } & \multirow[b]{2}{*}{$\begin{array}{c}\text { Percentage by } \\
\text { weight of } \\
\text { grain }\end{array}$} & \multicolumn{2}{|c|}{ Protein in fraction } \\
\hline & & Per cent. & $\begin{array}{l}\text { As percentage of } \\
\text { total protein } \\
\text { in grain }\end{array}$ \\
\hline Endosperm & $83 \cdot 5$ & $11 \cdot 1$ & $73 \cdot 3$ \\
\hline Bran .. & $15 \cdot 0$ & $18 \cdot 7$ & $22 \cdot 3$ \\
\hline Germ $\quad$. & $1 \cdot 5$ & $36 \cdot 7$ & $4 \cdot 4$ \\
\hline
\end{tabular}

weight of the grain, contains more than one-fifth of the total protein; this is due to the cells of the aleurone layer which, though morphologically the outer layer of the endosperm, is firmly adherent to the pericarp and is not separated in the ordinary processes of milling. According to Girard the aleurone layer forms about two-thirds of the weight of the bran and contains three-quarters of its nitrogen; or 16 per cent. of the total protein of the grain. The loss of nitrogen in the offals during milling of wheat to white flour is thus a serious one. 


\section{Quality of Proteins}

The proteins which have been isolated from wheat include albumins, globulins soluble in salt solution, and alcohol soluble proteins or prolamines. Of the last, the best studied is gliadin, the chief protein of the endosperm, which with the albumin, glutenin, composes the gluten of white flour. The proteins which have been isolated from different portions of the grain have been found to contain different amounts of carbon, hydrogen, nitrogen and sulphur, and to be composed of differing proportions of amino-acids. Thus, the albumin isolated from bran had a composition different from that of white flour glutenin (Jones and Gersdorff, 1923; Osborme and Vorhees, 1893). The prolamine from bran and the gliadin from endosperm had a different amino-acid composition and the same was true of the globulin from bran and the globulin isolated from the embryo (Jones and Gersdorff, 1926). One feature of the composition of the bran proteins was a higher content of lysine and tryptophane, both essential amino-acids, the former specially necessary for support of growth in young animals.

\section{Biological Value of Proteins}

The biological value of proteins has been studied experimentally by animal experiments of two types. In the first or "balance sheet" method, an estimation is made of the value of the protein for maintaining nitrogenous equilibrium. Such experiments can be made with adult or growing animals (Mitchell, 1924). They are laborious, can only be continued for a limited period and frequently give irregular results. Good summaries of results obtained with different wheat flours are given by Boas-Fixsen (1935) and by McCollum, Orent-Keiles and Day (1939). In comparable experiments, the proteins of whole wheat flour and of the embryo were consistently found to be of greater value than those of white flour.

The second type of experiment is based on observations of the rate of growth of young animals maintained for a relatively long period on a diet in which all nitrogen is provided by the protein to be investigated. All vitamins and other nutritive essentials must be provided in optimum amount, the protein which should be sub-optimal in amount being the only factor limiting growth. This method, first used by McCollum and his co-workers, was developed by Osborne and Mendel who found that the weight increase in g. per g. protein ingested was a useful index for comparison of the nutritive value of different proteins, when these proteins formed the same proportion of similarly composed diets and were given to comparable growing animals (Osborne, Mendel and Ferry, 1919). In tests of this type the mixture of proteins in the whole wheat grain was found consistently superior to those of white flour, and the proteins of the embryo were found to possess a nutritive value about equal to those of milk (Hove and Harrel, 1943).

In a series of experiments carried out in the Division of Nutrition of the Lister Institute (Chick, 1942) comparison was made of the nutritive value, for support of growth in young rats, of the proteins contained in flours of different degrees of extraction, care being taken that in each case all the flours compared were derived from the same sample of wheat. To achieve this we were indebted to the Research Association of British voL. 4, 1946] 
Flour-Millers, now the Cereals Research Station of the Ministry of Food, without whose help satisfactory materials could not have been obtained. Table 2 shows the results of two typical experiments in which comparison

TABLE 2

Biologrcal Value and Coefficient of Digestibility of the Protein of Flours of Different Dejgrees of Extraction

(Average values per rat for groups of 5 to 8 rats over a period of 5 weeks)

(Chick, 1942)

\begin{tabular}{|c|c|c|c|c|c|c|}
\hline \multirow{2}{*}{$\begin{array}{l}\text { Percentage } \\
\text { extraction of } \\
\text { flour in diet }\end{array}$} & \multirow{2}{*}{$\begin{array}{c}\text { Dry food } \\
\text { eaten } \\
\text { g. }\end{array}$} & \multirow{2}{*}{$\begin{array}{l}\text { Protein } \\
\text { eaten } \\
\text { g. }\end{array}$} & \multicolumn{2}{|c|}{$\begin{array}{c}\text { Bodyweight } \\
\text { g. }\end{array}$} & \multirow{2}{*}{$\begin{array}{l}\text { Growth } \\
\text { promoting } \\
\text { value of } \\
\text { protein* }\end{array}$} & \multirow{2}{*}{$\begin{array}{c}\text { Coefficient } \\
\text { of digesti- } \\
\text { bility } t\end{array}$} \\
\hline & & & Initial & Final & & \\
\hline \multicolumn{7}{|l|}{ Experiment 1} \\
\hline 100 & 317 & $39 \cdot 9$ & $46 \cdot 0$ & $117 \cdot 0$ & $1 \cdot 77$ & $83 \cdot 2$ \\
\hline 85 & 276 & $34 \cdot 5$ & $45 \cdot 0$ & $102 \cdot 0$ & 1.67 & $85 \cdot 4$ \\
\hline 75 & 246 & 30.9 & $46 \cdot 0$ & $91 \cdot 0$ & $1 \cdot 48$ & $87 \cdot 9$ \\
\hline \multicolumn{7}{|l|}{ Experiment 2} \\
\hline 100 & 339 & $41 \cdot 7$ & $47 \cdot 5$ & $117 \cdot 5$ & $1 \cdot 68$ & $81 \cdot 7$ \\
\hline 85 & 317 & $38 \cdot 9$ & $48 \cdot 5$ & $108 \cdot 0$ & 1.54 & $83 \cdot 6$ \\
\hline 73 & 281 & $34 \cdot 9$ & $49 \cdot 0$ & $95 \cdot 0$ & $1 \cdot 33$ & $86 \cdot 8$ \\
\hline
\end{tabular}

* Growth promoting value $=\frac{\text { weight increase, } g \text {. }}{\text { protein eaten, } g \text {. }}$

+ Coefficient of digestibility $=100 \times \frac{\text { nitrogen ingested }- \text { nitrogen in faeces }}{\text { nitrogen ingested }}$

was made between the proteins contained in whole wheat flour, in National flour of 85 per cent. extraction, and in ordinary "straight run" white flour of 73 to 75 per cent. extraction. All the diets contained about 12 per cent. of protein.

As the degree of extraction decreased, so the growth rate of the animals diminished. The rats ate more of the wholemeal diet than of the diets containing the National or white flour, but they also made better use of it.

The ranges of the nutritive values, measured by the expression of Osborne, Mendel and Ferry (1919), in wholemeal, 85 per cent. and 73 to 75 per cent. extraction flours were, respectively, 1.68 to $1 \cdot 77,1.54$ to 1.67 and $1 \cdot 21$ to 1.48 . The results showed an advantage over the proteins in white flour of 17 to 26 per cent. for proteins of wholemeal and of 13 to 16 per cent. for those of flour of 85 per cent. extraction.

This type of experiment has been criticized on the grounds that, since the animals were allowed to consume the diets ad libitum and growth rate depends primarily on the calorie intake, the greater palatability of the diet containing the wholemeal, and not the higher nutritive value of its protein, was the factor responsible for the better performance of the rats eating it (Wright, 1941). Mitchell, Hamilton and Shields (1943), however, settled this point by showing that the weight increase of young rats on a diet of wholemeal bread was greater than that of littermates on a diet of white bread, whether the consumption of the former was limited to that of the latter, or whether both diets were freely consumed. 


\title{
Digestibility of Proteins
}

Trials on animals and human subjects have shown that the proteins as contained in wholemeal are less well utilized than those in white flour. Macrae and his 5 volunteers (Macrae, Hutchinson, Irwin, Bacon and McDougal, 1942) found the average coefficients of apparent digestibility of the nitrogen in bread made from flours of 100 per cent. and 73 per cent. extraction to be, respectively, 85.5 and 91 . In the case of the rats, whose performance is summarized in Table 2 , the respective average coefficients were $82 \cdot 4$ and $87 \cdot 3$. This loss of about 6 per cent. in digestibility was, however, more than compensated by the greater nutritive value of the proteins of the wholemeal flour.

\section{REFERENCES}

Boas-Fixsen, M. A. (1935). Nutr. Abstr. Rev. 4, 447.

Chick, H. (1942). Lancet, 242, 405.

Girard, A. (1884). Ann. Chim. (Phys.) S'ér. VI, 3, 289.

Hove, E. L. and Harrel, C. G. (1943). Cereal Chem. 20, 141.

Jones, D. B. and Gersdorff, C. E. F. (1923). J. biol. Chem. 58, 117.

Jones, D. B. and Gersdorff, C. E. F. (1926). J. biol. Chem. 64, 241.

Macrae, T. F., Hutchinson, J. C. D., Irwin, J. O.,"Bacon, J. S. D. and McDougall, E. I. (1942). J. Hyg., Camb., 42, 423.

McCollum, E. V., Orent-Keiles, E. and Day, H. G. (1939). The Newer Knowledge of Nutrition, 5th ed., Appendix. New York: The Macmillan Co.

Mitchell, H. H. (1924). J. biol. Chem. 58, 873.

Mitchell, H. H., Hamilton, T. S. and Shields, J. B. (1943). J. Nutrit. 25, 585.

Osborne, T. B. and Mendel, L. B. (1919). J. biol. Chem. 37, 557.

Osborne, T. B., Mendel, L. B. and Ferry, E. L. (1919). J. biol. Chem. 37, 223.

Osborne, T. B. and Vorhees, C. G. (1893). Amer. Chem. J. 15, 392.

Wright, M. D. (1941). Brit. Med. J. ii, 689.

\section{Vitamin Values of Different Types of Flour}

\author{
Miss A. M. Copping (Division of Nutrition, Lister Institute, \\ London, S.W.1)
}

\section{Carotenoids}

From the standpoint of vitamin nutrition the main importance of the wheat grain lies in its content of the $\mathbf{B}$ vitamins. The biologically active carotenoids of wheat constitute only a small part of the total pigments present in the grain. Early colorimetric estimations had appeared to indicate a fairly high carotene content in some varieties of wheat but later colorimetric and biological tests have not shown similar results. The carotene appears to be evenly distributed in the different parts of the grain, since biological tests with rats have indicated that the animals survive for approximately the same length of time when unbleached white flour of 73 per cent. extraction or wholemeal flour of 92 per cent. extraction from the same grist is the sole source of vitamin $A$ in the diet (Hume, unpublished work).

\section{Vitamin $E$}

The germ of the wheat grain is one of the richest natural sources of vitamin $\mathrm{E}$ (tocopherol) and was the form of the vitamin most generally used until synthetic tocopherols became available. By means of a chemical method of estimating tocopherols with a ferric chloride reagent, vor. 4, 1946] 